\title{
LIBERDADE DE EXPRESSÃO E EXPRESSÕES DE ÓDIO *
}

\author{
Júlio César Casarin Barroso Silva
}

FREEDOM OF SPEECH AND HATE SPEECH

\section{RESUMO}

TOMANDO DECISÕES da SupRema CORTE dOS Estados UNIDOS COMO CORPUS EMPÍRICO E PONTO DE PARTIDA DESTE TRABALHO. ABORDAMOS AQUI DILEMAS DA LIBERDADE DE EXPRESSÃO OU, MAIS ESPECIFICAMENTE, A ESPINHOSA QUESTÃO NORMATIVA DE COMO TRATAR AS CHAMADAS EXPRESSÕES DE ÓDIO (RACISMO, MACHISMO, HOMOFOBIA OU OUTRAS FORMAS DE INTOLERÂNCIA) EM UM REGIME DEMOCRÁTICO: CENSURAR EXPRESSÕES INTOLERANTES IMPLICA IMPEDIR O ACESSO DE PARTE DO DEMOS À ESFERA PÚBLICA. NO ENTANTO, EXPRESSÕES DE ÓDIO PODEM AFETAR GRAVEMENTE OS DIREITOS, AS OPORTUNIDADES OU MESMO A INTEGRIDADE FÍSICA DE MINORIAS.

AO REJEITAR TANTO O LIVRE CURSO DE EXPRESSŌES DE ÓDIO QUANTO A PROIBICTÃO TOUT COURT DE TODA E QUALQUER EXPRESSĀO QUE POSSA SER CONSIDERADO INTOLERANTE, TENTAMOS OFERECER PARÂMETROS NORMATIVOS PARA A REGULAC̣ÃO DESSE GÊNERO DE DISCURSO.

\section{PALAVRAS-CHAVE}

LIBERDADE DE EXPRESSĀO; EXPRESSĀO DE ÓDIO; SUPREMA CORTE; DEMOCRACIA.

\section{ABSTRACT}

TAKING UnItED StATES SUPREME COURT'S DECISIONS AS THE EMPIRICAL BASIS AND POINT OF DEPARTURE OF THIS PAPER, MY INTENTION HERE IS TO APPROACH A CLASSICAL DILEMMA OF FREE SPEECH: THE NORMATIVE PROBLEM OF HOW TO HANDLE WITH HATE SPEECH IN A DEMOCRATIC SYSTEM. CENSORING THIS KIND OF SPEECH PREVENTS PART OF THE DEMOS TO GET INTO THE PUBLIC SPHERE. ON THE OTHER HAND, HATE SPEECH CAN SERIOUSLY DAMAGE RIGHTS, OPPORTUNITIES AND EVEN PHYSICAL INTEGRITY OF MINORITIES.

BY REJECTING BOTH COMPREHENSIVE LIBERALIZATION AND COMPLETE BAN OF EVERY OF INTOLERANT EXPRESSIONS, WHAT I TRY TO OFFER HERE IS SOME REFLECTION ON NORMATIVE GUIDELINES TO THE REGULATION OF THIS KIND OF SPEECH.

\section{KEYWORDS}

FREEDOM OF SPEECH; HATE SPEECH; SUPREME COURT; DEMOCRACY.

\section{INTRODUÇÃO}

Este artigo procura oferecer uma reflexão sobre um problema clássico de acomodação de liberdades fundamentais e um conhecido dilema da teoria política liberal: o 
problema da tolerância para com os intolerantes. Mais especificamente, nosso interesse primordial diz respeito à conveniência de se estender a liberdade de expressão a discursos com conteúdo intolerante.

Para tanto, tomamos a experiência constitucional estadunidense como ponto de partida. As razões para isso residem não apenas na sofisticação de uma discussão que desconhece as fronteiras acadêmicas entre o direito constitucional e a teoria política, mas também no aspecto exemplar que a liberalização discursiva assumiu naquele país, inclusive para com aquilo que podemos chamar de expressões de ódio, tratadas pelo direito constitucional estadunidense com uma permissividade sem paralelo em outras experiências democráticas, que costumam excluir da proteção à liberdade de expressão ao menos certas categorias de expressões abertamente racistas.

Se, por um lado, o sistema estadunidense parece-nos inadequado, por razões que veremos adiante, tampouco nos parece defensável a criminalização tout court de toda e qualquer forma de expressão intolerante. A questão, portanto, é oferecer parâmetros normativos que permitam preservar simultaneamente a liberdade de expressão e a dignidade de minorias.

Dada a importância da experiência estadunidense na construção de nossos próprios argumentos, seria proveitoso passarmos em revista os principais parâmetros de proteção constitucional à liberdade de expressão naquele país antes de entrarmos em nosso tema substantivo.

\section{A liberdade de expressão nos Estados Unidos}

Nas sínteses de David Strauss (2003, p. 36-38) e de Cass Sunstein (1995, p. 5-14), a proteção constitucional à liberdade de expressão nos Estados Unidos envolve duas questões distintas: uma diz respeito ao valor da expressão, e outra inquire sobre a neutralidade da regulação.

Quanto ao valor da expressão, há expressões de "alto valor", que gozam de proteção constitucional plena, e expressões de "baixo valor", que contam com uma proteção menos efetiva. A linha que as separa, contudo, é pouco precisa, e a Suprema Corte jamais conseguiu dotá-la de clareza. A expressão que se mantém no centro da proteção constitucional não pode ser regulada, ou, em alguns casos, exige, para que se possa regulá-la, a condição da iminência de causar um dano muito significativo. Outras formas de expressão estão localizadas na periferia do sistema constitucional de proteção. Por terem "baixo valor”, podem ser reguladas, mas mesmo nesse caso se exige uma justificativa razoável e plausível, menos exigente que a exigida pela expressão de "alto valor". A expressão claramente política, qualquer que seja a sua natureza, como dissemos, está no centro da proteção constitucional: trate-se de um discurso comunista, ultraliberal ou mesmo de um discurso carregado de ódio racial feito por um membro da Klu Klux Klan, ou ainda de uma passeata neonazista em uma 
cidade repleta de sobreviventes dos campos de concentração nazistas, a expressão goza de imunidade. Diz o cânone da Primeira Emenda (o dispositivo da Constituição que protege a liberdade de expressão) que o remédio para as expressões perniciosas é mais discussão, e não menos. ${ }^{1}$ Tal centralidade do discurso político e do direito de criticar o governo é o resultado direto do caso NewYork Times v. Sullivan, e também de Brandenburg. ${ }^{2}$ A regra resultante da combinação desses dois casos é, como disse Rawls, a de que em uma sociedade livre não podemos difamar o governo não porque sejamos de alguma forma proibidos de fazê-lo, mas "porque tal crime não existe" (RAWLS, 2000, p. 412).

Contudo, outras formas de expressão têm menos valor. A expressão comercial, por exemplo, goza de alguma proteção constitucional, mas comerciais enganosos podem sofrer intervenção governamental. A difamação de figuras privadas tampouco goza de muita proteção (contraposta à difamação de "figuras públicas", que pertence ao grau mais alto de proteção: no caso de a difamação dirigir-se a pessoas que não se encaixem na definição de figuras públicas, é bem mais fácil ao difamado processar seu difamador). Já a expressão qualificada como obscena ${ }^{3}$ está fora do âmbito constitucional de proteção, em tese. A definição atual de obscenidade é de 1973, do caso Miller v. Califórnia, ${ }^{4}$ e é a expressão que simultaneamente apele a "interesses lascivos", seja "patentemente ofensiva" e "desprovida de valor social" (o que exclui a arte, a ciência e a política). Mas esses critérios são entendidos de forma tão estrita que na prática se tornaram pouco efetivos (do ponto de vista da censura). Aquele que deseja publicar pornografia não tem um motivo forte para temer ser censurado.

O fato de a expressão de baixo valor ser definida em termos muito mais precisos que a expressão de alto valor faz com que não seja necessário ao falante demonstrar que sua expressão pertence à categoria superior: basta demonstrar que não pertence às categorias inferiores para que adquira o nível mais alto de proteção de modo automático. Não é preciso demonstrar que a expressão é artística, política ou científica: uma vez que não se trate de ameaça, por exemplo, ela estará protegida.

A outra questão diz respeito à neutralidade da regulação. De acordo com a tipologia desenvolvida pela Corte, uma regulação pode ser "neutra quanto a conteúdo", "baseada no conteúdo" ou "baseada no ponto de vista”, em ordem crescente de presunção de inconstitucionalidade. Uma restrição é neutra quanto ao conteúdo quando este é completamente indiferente aos propósitos da restrição. A proibição de uso de alto-falantes nas imediações de hospitais, por exemplo, é neutra quanto ao conteúdo, pois a restrição aplica-se não importa o conteúdo da mensagem que se transmitiria pelos alto-falantes. A restrição baseada no conteúdo, por sua vez, pode não ser injusta no sentido de atingir um dos lados da discussão: a proibição de discutir a legitimidade de uma guerra no interior dos quartéis (que é um tipo de restrição aceita), ou de discutir questões raciais ou o divórcio em qualquer lugar, por exemplo, são discussões baseadas no conteúdo, mas recaem tanto sobre aqueles que 
defendem o divórcio quanto sobre aos que a ele se opõem. Já as discussões baseadas no ponto de vista restringem a expressão de um dos lados de uma discussão, proibindo a crítica à participação do país em uma guerra, ou a defesa dos direitos civis plenos para homossexuais.

No sistema constitucional contemporâneo nos Estados Unidos, a forma que a restrição assume, claro, é importantíssima para definir sua legitimidade. Essa questão deve ser superposta ao problema do valor da expressão, embora sejam reciprocamente independentes. Restrições neutras quanto ao conteúdo podem valer mesmo para expressões do mais alto valor, como expressão política. Sunstein (1995, p. 12-13) exemplifica com uma proibição hipotética de distribuição de panfletos em aeroportos, e, por se estar próximo de uma eleição, a proibição acaba atingindo os voluntários que fazem panfletagem por seu candidato preferido. É perfeitamente possível (embora isso não seja absolutamente certo) que as cortes sustentem a proibição, dentro do sistema contemporâneo. Podemos imaginar ainda restrições sobre expressão de pequeno valor baseadas no ponto de vista: imaginemos que o governo penalize com mais rigor ameaças feitas, digamos, a militantes do Partido Verde, depois de uma onda de assassinatos de militantes desse partido. Temos uma expressão não protegida (ameaça) sobre a qual recaem restrições baseadas no ponto de vista que são aceitáveis.

A presunção mais forte de inconstitucionalidade, como se pode imaginar, recai sobre as restrições baseadas no ponto de vista, embora a inconstitucionalidade não seja automática, como podemos perceber pelo exemplo anterior. As restrições feitas com base no conteúdo também contam com uma forte presunção de inconstitucionalidade, embora não tão forte quanto a que pesa sobre as restrições baseadas no ponto de vista. Em algumas áreas determinadas, restrições baseadas no conteúdo são perfeitamente aceitáveis, como as restrições à publicidade enganosa, ou à difamação (exceto no caso de "pessoas públicas"), ou à obscenidade (significativamente, nenhuma dessas restrições é baseada no ponto de vista). Mas restrições baseadas no conteúdo sobre expressões de alto valor são presumivelmente inconstitucionais.

Já as restrições neutras quanto ao conteúdo podem eventualmente ser consideradas constitucionais, desde que submetidas a alguma técnica de sopesamento entre os interesse em jogo. Mas é sempre necessário ter certa prudência com relação a essas regras. Restrições aparentemente neutras quanto ao conteúdo podem afetar de modo desproporcional determinados grupos políticos, o que nos pode levar a concluir por sua inconstitucionalidade. Uma eventual proibição de que se usem as ruas e avenidas como palco de protesto - neutra quanto ao conteúdo, em tese - pode atingir de forma desproporcional os grupos políticos para os quais esse tipo de manifestação é crucial. Na prática, portanto, pode tratar-se de uma restrição baseada no ponto de vista disfarçada de neutra quanto ao conteúdo. Como disse David Rabban, banqueiros não precisam de encontros de massa e de entregar folhetos para se fazerem ouvir, 
mas os trabalhadores sim, já que essa podia ser a única possibilidade de expressão do grupo: "oradores de caixote" normalmente "não têm dinheiro ou conexões sociais para alugar outro local” (RABBAN, 1997, p. 110).

\section{O ÓdiO COMO PROBlema POLÍtico: RACISMO, HOMOFOBIA E MISOGINIA}

O reconhecimento de que a proteção à expressão política constitui o "significado central da Primeira Emenda” no sistema contemporâneo de liberdade de expressão nos Estados Unidos teve uma dimensão igualitária evidente, ao estender a proteção constitucional a todo o espectro político, independentemente de avaliações de mérito sobre o conteúdo do discurso. Entretanto, a sobrevivência de grupos com convicções abertamente racistas coloca um novo desafio ao problema da igualdade política. Reprimir a expressão desses grupos - argumenta-se - seria amputar o leque político de uma de suas alas, impedindo o acesso de parte do espectro ideológico à esfera pública deliberativa. No entanto, dar-lhes livre curso pode causar sérios danos a integrantes de grupos étnicos e sociais minoritários. Críticos do modelo atual de liberdade de expressão nos Estados Unidos veem a permissibilidade com que tais expressões são tratadas como um instrumento de corrosão da liberdade, da igualdade política e mesmo da integridade física das minorias agredidas. ${ }^{5}$

Antes de passarmos à discussão do tema, apresentaremos os casos judiciais que moldaram o tratamento judicial contemporâneo da questão nos Estados Unidos.

\section{I CASOS-CHAVE ENVOLVENDO RACISMO E EXPRESSÕes DE Ódio}

Um caso importante foi Beauharnais v. Illinois. ${ }^{6}$ Uma lei estadual de Illinois criminalizava a publicação ou exibição de publicação que retratasse "depravação, criminalidade, lubricidade ou falta de virtude de um grupo de cidadãos, de qualquer raça, cor, credo ou religião" ou que expusesse "qualquer raça, credo ou religião a desprezo, escárnio, vilipêndio" e que por isso fosse capaz de produzir a "quebra de paz ou distúrbios”. Joseph Beauharnais foi condenado por organizar uma manifestação instando as autoridades públicas municipais de Chicago a impedir "a invasão de bairros brancos pelos 'niggers' (um termo terrivelmente depreciativo para referir-se a afro-descendentes) e a impedir a 'mistura' destes - associados em um panfleto a 'agressões, estupros, roubos, facas, armas de fogo e maconha' - com a 'raça branca [sic]'”. O juiz Frankfurter, falando pela Corte em uma decisão tomada por estreita maioria de 5 a 4, apoiou a lei de Illinois. Não o fez, contudo, em nome de alguma concepção de igualdade ou com o intuito de proteger a minoria atacada no panfleto, mas baseando-se na histórica exclusão da difamação (libel) da categoria de expressão constitucionalmente protegida, na necessidade de deferência judicial ao Poder Legislativo em se tratando de matéria controversa e complexa e, fundamentalmente, nos riscos que expressões de ódio poderiam trazer à coesão e à harmonia social. ${ }^{7}$ 
A decisão de Frankfurter encontrava respaldo em decisões anteriores da Corte e na tradição do sistema jurídico estadunidense, que excluíam a categoria de Fighting $W_{\text {ord }}{ }^{8}$ da proteção conferida pela Primeira Emenda. O caso que colocou definitivamente essa categoria de expressão fora da proteção conferida pela Primeira Emenda foi Chaplinsky v. State of New Hampshire. ${ }^{9}$ Chaplinsky, fiel da confissão "Testemunhas de Jeová", usando a calçada como espaço de proselitismo religioso, causou tumulto ao afirmar que qualquer tipo de religião organizada era uma "fraude". Sendo levado à delegacia, chamou o delegado de "maldito fascista" e de "farsante amaldiçoado por Deus”, razão pela qual foi condenado e recorreu à Suprema Corte reivindicando liberdade de expressão. Sua condenação foi mantida com base em que suas palavras não eram "a parte essencial de nenhuma exposição de ideias”, o que diminuía seu valor, considerado menor em face do "interesse social na ordem e na moralidade". As "palavras de luta" são entendidas, portanto, como uma categoria estreitamente definida de expressões que, na qualidade de mero insulto, podem causar uma briga por constituírem nada mais do que um chamado à violência física. Para se encaixar nessa definição, contudo, uma expressão deve ter baixíssimo apelo deliberativo, por assim dizer, i.e., não pode ter chance de ser entendida como um convite à troca de ideias. Suprimir expressões com estas características ainda é considerado aceitável - ao menos em tese - já que isso não representaria o banimento de nenhuma ideia em particular (no jargão constitucional estadunidense, seria "neutro quanto ao conteúdo"). Mencionamos esta categoria pelo fato de que muitas vezes ela se relaciona, se superpõe e se confunde com o que podemos chamar de expressões de ódio. Entretanto, O’Brien afirma que na prática dos tribunais a categoria de fighting words é tão estreitamente definida e aplicada que ela pode ser considerada carta fora do baralho do sistema (O’BRIEN, 2005, p. 479).

Não podemos deixar de mencionar ainda um caso cujo mérito não chegou a ser decidido pela Suprema Corte, mas que se tornou emblemático do quão longe se leva a tolerância para com expressões de ódio com base na centralidade da expressão política. É o caso de Skokie, subúrbio de Chicago cujos cidadãos são em grande parte de origem judaica, entre os quais se contava, à época dos eventos aqui narrados (na década de 1970) número significativo de sobreviventes do Holocausto (estima-se que um número entre 7.000 e 8.000 sobreviventes da Shoah emigraram para Skokie) (REICH, 2013). Foi aí que, provocativamente, o Partido Nazista dos Estados Unidos decidiu fazer uma manifestação, marchando pela cidade portando suas suásticas e outros símbolos de ódio. Apesar dos esforços jurídicos e políticos das autoridades locais para impedir a manifestação, o Partido Nazista recebeu a permissão do Sétimo Circuito da Justiça Federal estadunidense para realizá-la (LEWIS, 2007, p. 160). ${ }^{10}$ A marcha acabou não se realizando por decisão dos neonazistas, que a transferiram para Chicago. O que nos interessa aqui, contudo, é o fato de que o Judiciário a autorizou com base na liberdade de expressão. Lewis informa ainda que a conhecida organização de defesa dos 
direitos civis (American Civil Liberties Union - ACLU) enfrentou uma crise por conta desse caso, uma vez que a direção da organização (frequentemente libertária tout court em se tratando de liberdades civis) apoiou o suposto direito dos nazistas de marchar pela cidade, o que levou muitos membros da entidade a se desfiliarem em protesto. A direção, contudo, não arredou o pé de sua posição.

Mais recentemente, o caso R.A.V. v. City of Saint Paul, ${ }^{11}$ no qual a Corte considerou unanimemente inconstitucional uma lei local da cidade de Saint Paul (em Minnesota) que tratava de expressões de ódio, é que constitui o paradigma fundamental. Os fatos que deram origem a R. A. V. foram os seguintes: Robert A. Viktora, um adolescente branco, foi condenado por ter queimado, com outros amigos, uma cruz de madeira no quintal de uma família negra. Como se sabe, a queima de cruzes é nos Estados Unidos uma forma de manifestação política de grupos racistas, defensores da "supremacia branca" e da segregação racial, sendo frequentemente associada à Ku Klux Klan (KKK). Mas ao mesmo tempo em que traduz uma manifestação política, racista e, no nosso entender, abjeta, mas uma manifestação com conteúdo claramente político, enfim, a queima de cruzes é muitas vezes usada como "advertência”, ou, fazendo as pazes com o léxico e chamando as coisas pelo nome que têm, como ameaça a negros e a membros de outras minorias que desafiam as regras de separação racial defendidas pela KKK e por grupos similares.

Não sabemos se a ação se resumiu a uma brincadeira de mau gosto de adolescentes desocupados ou se se tratava de uma ameaça real à família negra. Mas as circunstâncias do caso concreto interessam-nos menos aqui do que a decisão da Corte e a moralidade política que a sustenta. O fato é que os adolescentes foram presos e julgados por violação de uma lei local de 1989 que criminalizava a exibição de cruzes ardentes, suásticas e quaisquer símbolos capazes de produzir "raiva, alarme e ressentimento em outros com base na raça, cor, credo, religião ou gênero” (apud O'BRIEN, 2005 , p. 499). Um tribunal juvenil estadual anulou a condenação pelo fato de que a lei reprimia uma gama demasiado ampla de manifestações, o que lhe atestaria a inconstitucionalidade. A Suprema Corte do estado de Minnesota reverteu essa decisão, mantendo a condenação e afirmando que o tipo de manifestação coibida pela lei era apenas aquela que estava fora do âmbito de proteção da Primeira Emenda, ou seja, expressões que pudessem ser qualificadas como "palavras de luta" e expressões capazes de produzir "ação ilegal iminente" (categorias historicamente desprotegidas pela Primeira Emenda). A Corte Estadual afirmou que "a queima de uma cruz é em si mesmo um símbolo cabal de violência e ódio baseados em noções virulentas de supremacia racial. É responsabilidade, e talvez até mesmo obrigação das diversas comunidades enfrentar semelhantes noções em todas as formas nas quais elas se manifestarem" (apud O’BRIEN, 2005, p. 499). A lei de Saint Paul seria constitucional porque não bania a queima de cruz per se, e sim a queima de cruz capaz de criar raiva, alarme ou ressentimento por meio de viés racial, sexual, religioso ou étnico. Viktora apelou 
então à Suprema Corte com a esperança de reverter essa decisão, o que conseguiu através de uma decisão unânime (O’BRIEN, 2005, p. 499-500).

Finalmente, não poderíamos deixar de abordar os ruidosos casos que envolvem os códigos de expressão estabelecidos por diversas universidades nos Estados Unidos com o intuito de coibir o racismo nos campi.

\subsection{OS CÓDIGOS UNIVERSITÁRIOS DE REGULAÇÃO DA EXPRESSÃO}

Em abril de 1989, estudantes da Universidade de Michigan depararam-se com mensagens racistas na sala de aula, segundo as quais os esforços intelectuais de niggers eram "desperdício". Pouco tempo depois, a mesma universidade foi o espaço de circulação de panfletos que declaravam "aberta a temporada de caça aos negros". Um mês mais tarde, uma aluna africana do Smith College, em Massachusetts, encontrou uma mensagem sob a porta de seu quarto na qual se lia: "Nigger africana, você quer bananas? Volta para a floresta”. ${ }^{12}$

Em resposta a este e a outros casos, um número significativo de universidades estadunidenses adotou códigos de conduta que estabeleciam restrições a expressões racistas e a outras formas de expressões de ódio em seus campi (LEWIS, 2007, p. 163), o que desencadeou clamorosa controvérsia pública. Não tardou até que um juiz federal, Avern Cohn, declarasse inconstitucional o código de expressão da Universidade do Michigan. 13

Stanford, uma universidade privada, foi uma das instituições que adotaram um código como esses, o qual alvejava expressões que: 1) tivessem a intenção de insultar ou estigmatizar indivíduos com base em raça, sexo, cor, religião, deficiência, orientação sexual ou origem étnica ou nacional; 2) fossem dirigidas diretamente ao(s) indivíduo(s) que ela insulta ou estigmatiza; e 3) fizessem uso de palavras insultantes ou de luta ou símbolos não verbais "comumente entendidos como expressão de ódio direto e visceral ou desprezo por seres humanos com base em seu sexo, raça etc.” (apud COHEN, 1993, p. 208). Pelo código, as expressões seriam reguláveis se e somente se essas três condições fossem simultaneamente satisfeitas. Tal exigência tornaria eventuais restrições à expressão raras e evitaria exageros persecutórios.

Muito embora o objetivo desses regulamentos fosse inicialmente o de combater o assédio contra minorias nos campi, acabaram por alvejar outros tipos de expressão. A Universidade de Massachusetts em Amherst acrescentou outra lista de categorias protegidas em seu próprio código, que incluía "idade, estado civil, condição de veterano de guerra". O centro acadêmico fez campanha para que o código protegesse ainda as pessoas de expressões que as insultasse quanto a "cidadania, cultura, condição quanto ao HIV, língua, situação parental, inclinação política e gravidez” (LEWIS, 2007, p. 163). A inclusão de tantas categorias protegidas contra expressões que pudessem causar raiva teve o condão de expor a campanha a certo ridículo, o que a fez minguar de forma definitiva poucos anos mais tarde, quando o Código de Stanford foi invalidado 
judicialmente, não muito tempo depois de o código da Universidade de Michigan ter sido declarado inconstitucional por uma corte federal.

\subsection{NeUtralidade, iguAldAde POlítica E LIBERdAdE DE EXPRESSÃo}

Apesar de decisões judiciais lenientes para com expressões de ódio racial como algumas das mencionadas acima serem em certo sentido perturbadoras para aqueles que acreditamos na igualdade humana fundamental como valor normativo e princípio de legitimidade política, devemos reconhecer que o fundamento de tais decisões está longe de ser tolo ou pouco sofisticado. O que as sustenta não é necessariamente um liso endosso ideológico dos juízes ao racismo dos acusados, mas sim uma racionalidade inteiramente compatível com o sistema de ampla liberdade de expressão vigente nos Estados Unidos e com uma concepção de democracia que, a seu modo, não deixa de ser inclusiva, já que é baseada em um entendimento da igualdade política que, embora não seja o nosso nem nos pareça o mais justo, reconhecemos defensável.

A partir de agora, portanto, discutiremos os argumentos frequentemente levantados no debate em torno da conveniência ou não da supressão de expressões de ódio. Como dissemos, o eixo das discussões reside tanto no problema da centralidade das expressões políticas quanto na ideia de neutralidade do Estado e na concepção de igualdade política abraçada por suas instituições.

Comecemos pelos caso mais específico, o das universidades, instituições nas quais vige uma lógica especial no que se refere à liberdade de expressão. Como argumenta Sunstein, não é possível levar adiante a tarefa educacional se não se estabelecem certos controles de expressão que não seriam aceitáveis em outros contextos: os programas dos cursos estabelecem limites aos tópicos em discussão em sala de aula, por exemplo; além disso, um professor pode exigir que os alunos se tratem entre si e tratem a ele, professor, com certo nível de respeito e de urbanidade. Evidentemente, essas restrições à expressão que a universidade está autorizada a colocar em prática não justificam outro gênero de controle. A universidade não pode, por exemplo, estabelecer uma ortodoxia política “oficial”, expulsando os alunos que não a abraçam. Eventuais restrições baseadas no conteúdo podem ser adotadas desde que se relacionem com o propósito educacional da instituição (SUNSTEIN, 1995, p. 197-208).

Nossa questão agora, portanto, é se não podemos incluir entre os controles legítimos que uma universidade pode exercer a restrição a certas expressões de ódio no seu interior. Será que não pode exigir que todos os alunos tratem os colegas como membros iguais da comunidade universitária, uma vez que expressões de ódio podem comprometer a capacidade de aprendizado dos estudantes oriundos de minorias? Com Sunstein, acreditamos que uma abordagem como esta é perfeitamente possível de ser sustentada, mesmo no contexto do sistema constitucional estadunidense, desde que as expressões de ódio censuradas fossem estreitamente definidas de forma a se encaixarem nos propósitos educacionais da instituição. Mais do que propriamente restrições 
de expressões de ódio, a Universidade pode impor a uma obrigação de decência e civilidade no trato interpessoal no interior dos campi (SUNSTEIN, 1995, p. 197-208). Isso justificaria restrições mais amplas do que as que se aceitam fora das universidades. Mesmo no sistema constitucional pós-R. A.V., uma universidade deveria poder regular, em bases suficientemente neutras, a) uma categoria estreitamente definida de insultos a grupos específicos e enumerados, como negros, mulheres e homossexuais, ou b) uma categoria estreitamente definida de insultos dirigidos a indivíduos envolvendo raça, sexo e orientação sexual. Sob a lei corrente, a restrição “a)” é baseada no ponto de vista, o que a faz mais problemática do que a lei derrubada por R.A.V., já que tenta silenciar um lado do debate. A restrição “b)" é uma restrição baseada no conteúdo, não no ponto de vista. Mas é seletiva no mesmo sentido que a lei invalidada no caso R.A.V. O que as tornaria aceitáveis é a sua aplicação restrita ao âmbito universitário. E esta é uma base suficientemente neutra (SUNSTEIN, 1995, p. 199).

Contudo, subordinar a aplicação desse princípio de supressão às necessidades educacionais não deve ser apenas uma formalidade: evitaria que ele fosse utilizado contra os propósitos do aprendizado, contra a liberdade de cátedra e protegeria o próprio conteúdo disciplinar contra exageros da correção política, como os narrados por Lewis, que afirma que um professor de direito em Harvard foi alvo de protestos por citar uma sentença do ex-juiz da Suprema Corte Robert H. Jackson, o qual, por sua vez, citava uma linha de um poema de Lord Byron no qual o poeta afirma que Julia, "jurando que jamais consentiria, consentiu” [“swearing she would ne'er consent, consented”] (LEWIS, 2007, p. 164). Ou evitaria que estudantes do curso de Letras pudessem exigir o banimento de Shakespeare, por exemplo, por se sentirem ofendidos por seu antissemitismo (pela forma como o personagem Shylock é retratado em O Mercador de Veneza) ou por sua islamofobia (por retratar o muçulmano negro Otelo como um assassino da própria esposa, e pela forma pouco gentil com que a mãe de Calibã, uma árabe muçulmana, é descrita por Próspero em A Tempestade) (FISK, 2008).

Mas como podemos avaliar o padrão estabelecido em R. A.V. para regular a discussão pública no tumulto da vida política e social que corre fora dos muros e dos critérios específicos das universidades? Neste ponto, temos de fazer uma avaliação mais técnica e presa ao debate específico sobre a lei e a Constituição dos Estados Unidos, mas podemos também dar a essa avaliação um caráter mais amplo (embora nem sempre as tecnicalidades do sistema estadunidense sejam eludíveis).

No que toca especificamente à queima de cruzes, um argumento frequentemente levantado é o de que este tipo de gesto não é expressão, mas conduta, o que lhe tiraria a proteção oferecida pela Primeira Emenda e pela liberdade que, no final das contas, é apenas de speech, termo que se aplicaria apenas a palavras e, no máximo, a imagens, mas não a gestos. A simplicidade e a singeleza deste argumento podem parecer sedutoras à primeira vista, mas não creio que subsista a uma análise mais cuidadosa. Se o aceitássemos, teríamos de aceitar - à revelia do bom senso, do direito constitucional 
e do escopo de proteger a expressão que tenha cunho político - que uma ampla gama de gestos expressivos simplesmente não goza de proteção. Que motivo teríamos para reivindicar uma regulação da expressão política que não protegesse a queima de uma bandeira, a participação em uma passeata, o uso de uma peça de vestuário que porta determinada mensagem? Como ressalta Sunstein, sob a perspectiva madisoniana e sua valorização dos pontos de vista sobre assuntos e temas públicos, a diferenciação entre palavras e conduta expressiva parece artificial e arbitrária (SUNSTEIN, 1995, p. 181). Mesmo condutas cujo significado político não seja evidente ou imediato, como a dança, por exemplo, precisam de uma base sólida para serem restringidas, e "base sólida", nesse caso, significa uma justificativa "suficientemente neutra" (SUNSTEIN, 1995, p. 182).

Vemos que a exigência de neutralidade se repete com insistência nos julgamentos da Suprema Corte. A prevenção contra restrições baseadas no ponto de vista é muito forte. Se tomamos outro exemplo de "conduta expressiva" que, ao menos em seu aspecto exterior, guarda alguma semelhança com a queima de cruzes, a saber, a queima de bandeiras, veremos que a Suprema Corte invalidou uma lei do Texas que criminalizava a queima da bandeira estadunidense. ${ }^{14}$ A sentença afirmava que a razão dada para a proibição era ilegítima, pois "o governo não tem uma razão para a regulação que seja independente da objeção governamental às ideias que a queima de bandeira traz" (a síntese é de SUNSTEIN, 1995, p. 182). Assim, parece que se tivermos uma razão mais robusta e mais neutra do que nosso desgosto pela ideia de racismo e segregação embutida na queima da cruz, talvez possamos ganhar terreno neste ponto.

Na decisão do caso R.A.V., a suposta ausência de neutralidade da lei de Saint Paul foi decisiva para a anulação da condenação dos rapazes e para a declaração da inconstitucionalidade da lei. Na sentença, o juiz Antonin Scalia afirmou que mesmo em uma categoria não protegida de expressão, como "palavras de luta”, o governo não estava autorizado a romper suas obrigações de neutralidade, penalizando a expressão de determinadas palavras com base em seu conteúdo ou ponto de vista (SUNSTEIN, 1995, p. 190). Não nos parece que esse argumento possa ser levado às últimas consequências. Se tentamos aplicar o argumento de Scalia a outra das categorias periféricas de expressão, como a expressão comercial, vemos que a tese é frágil. Do contrário, o governo não teria legitimidade para restringir a propaganda de cigarro, por exemplo, que mais do que uma restrição de conteúdo é uma restrição de ponto de vista. Por que motivo então uma categoria como "palavras de luta" não pode ser regulada como a expressão comercial? Ao que tudo indica, a lei de Saint Paul foi invalidada em R. A.V. por criminalizar não apenas palavras de luta, mas um espectro muito amplo condutas e expressões, abrindo a porta para censuras partisan fora do círculo da categoria desprotegida de expressão. Suponhamos que uma lei proíba a queima de cruzes que produza raiva ou ressentimento se e somente se a expressão em questão é também regulável sob padrões existentes de "palavras de luta”. Em Beauharnais, por 
exemplo, uma regulação de expressão racista foi aceita, embora muitos questionem a validade de Beauharnais depois de New York Times v. Sullivan, já que em Sullivan ${ }^{15}$ a Corte subordinou a lei de difamação (libel) às exigências de um debate público robusto (SUNSTEIN, 1995, p. 185). Expressões de ódio, entendeu a corte na festejada decisão, contêm ideias políticas que não podem ser suprimidas apenas porque são ofensivas.

Mas voltemos ao incontornável tema da neutralidade. Uma das motivações "neutras", no caso, seria, por exemplo, a de proteger a propriedade da família negra cujo quintal foi invadido pelos adolescentes racistas, com base no mesmo princípio que nos permitiria chamar a polícia se alguém entrasse em nossa casa e tentasse pichar nossas paredes. Queimar uma cruz no quintal de alguém já é proibido pela lei penal ordinária por violar o direito de propriedade, e podia justificar uma condenação criminal dos rapazes. ${ }^{16}$ Mas o que estava em questão, nesse caso, é se era legítimo considerar a mensagem trazida pela queima da cruz um crime adicional (DWORKIN, 1996, p. 204).

Em uma sociedade em que uma parcela mais ou menos significativa do espectro político recusa-se renitentemente a aceitar a ideia normativa de igualdade humana fundamental, o sistema de liberdade de expressão se confronta com um dilema: censurar sua expressão significa extirpar uma parcela do demos do sistema de expressão protegida, e sob certo aspecto, deixa de manifestar-se neutro em face do mesmo debate político. No entanto, permitir-lhes a expressão pode trazer consequências terríveis não só para a "harmonia social", como disse Frankfurter em Beauharnais, mas também para o ambiente igualitário que é condição imprescindível para que membros de minorias historicamente discriminadas e excluídas do processo político se sintam à vontade para participar desse processo. Em outras palavras, alguém deixará de ser tratado como igual, em algum sentido. Ou racistas, misóginos e homofóbicos são silenciados com base no ponto de vista do que dizem, ou se correrá o risco de criação de um ambiente político tão tenso no que se refere às divisões étnicas da sociedade que a participação das minorias pode tornar-se bastante difícil, entre outros possíveis danos.

Por ora, contudo, concentro-me na questão: o Estado viola a neutralidade ao penalizar os cidadãos que expressam rejeição à ideia de igualdade humana fundamental? A resposta a esta questão depende da concepção de neutralidade que se abrace. Robert Post, por exemplo, considera que uma moralidade política apoiada na neutralidade não pode endossar a censura de expressões racistas. Isso porque a igualdade humana fundamental é entendida por ele como uma perspectiva particular:

$\mathrm{Na}$ área de igual proteção [...] o governo federal tem, há quarenta anos, procurado inculcar de modo agressivo e em âmbito nacional valores particulares de igualdade. Mas a imposição legal desses valores só adquire legitimidade democrática precisamente pelo fato de que a Primeira Emenda 
estabeleceu uma arena de discurso público dentro da qual eles [os ideais de igualdade] podem ser livremente encampados ou rejeitados. (POST, 1995a, p. 278)

Post talvez tivesse razão se (e somente se) a aceitação ou não dos "valores particulares de igualdade” no âmbito da expressão não tivesse nenhum impacto sobre os direitos de outras pessoas, particularmente sobre os direitos das minorias insultadas. Parece plausível, no entanto, dar rédea solta a racistas para que insultem seus concidadãos em termos raciais não afete a distribuição social dos direitos? Em uma sociedade em que esses insultos são completamente livres, minorias raciais podem sentir-se constrangidas de ir à escola (a menos que seja uma escola segregada), falar em público ou até mesmo andar na rua (a menos que seja no gueto).

Em passagem de $A$ justiça como equidade, Rawls rebate a acusação de que a sua concepção de liberalismo político não seja suficientemente neutra, uma vez que nela não há espaço para todos os modos de vida possíveis, e seus argumentos podem ajudar-nos aqui. Para Rawls (2003, p. 218-219), determinadas doutrinas abrangentes do bem "podem ser desencorajadas" em uma sociedade liberal justa, seja por "entrar em conflito direto com os princípios de justiça”, seja por não conseguirem angariar seguidores "nas condições de um regime constitucional justo". Exemplo desse último caso seria, para Rawls, o de uma religião que "só possa sobreviver se puder controlar o aparato do Estado e puder praticar a intolerância" (idem). Como exemplo do primeiro caso, Rawls menciona concepções de bem que imponham "a repressão ou a degradação de certas pessoas por motivos, digamos, raciais, étnicos ou perfeccionistas" (idem). Uma sociedade justa em termos rawlsianos não seria "neutra” no sentido de que essas concepções de bem teriam ali livre curso, mas isso "não parece" ser uma injustiça, segundo Rawls, já que "é impossível evitar a existência de influências sociais que favoreçam algumas doutrinas em detrimento de outras" (idem), arrematando que "nenhuma sociedade pode incluir em si todos os modos de vida" em razão do "espaço limitado" do "mundo social" (idem).

Em uma sociedade justa, doutrinas assim "podem perdurar, mas sempre entre segmentos relativamente pequenos da sociedade" (RAWLS, 2003, p. 218), ou seja, continuaria a haver cidadãos que sustentam convicções racistas e intolerantes. O uso da força repressora do Estado contra esses cidadãos, contudo, não se justifica, em nosso entender, simplesmente por sua insistência em manter convicções como estas. Justifica-se, isso sim, no caso de que tentem colocar suas convicções em prática, privando outros cidadãos de seus direitos constitucionais, ameaçando-os, ou mesmo os ferindo. Neste caso, como disse Sebastião Nascimento em um texto não publicado,

defender a inércia das instituições repressivas diante da injustiça parece um tipo de minimalismo perverso. [...] [o avanço d]a política de implementação 
de direitos fundamentais depende também do refinamento dos instrumentos jurídicos de controle e repressão das condutas que limitam a liberdade. (NASCIMENTO, 2007, p. 3)

Temos, portanto, outra questão em mãos: a expressão de pontos de vista racistas e intolerantes é inofensiva, devendo ser tolerada, ou é capaz de causar danos sérios aos membros de minorias, privando-os de seus direitos constitucionais, devendo ser banida? No caso de sermos capazes de atestar uma relação mais ou menos direta entre a expressão de ódio e um dano físico ou uma privação de direitos à pessoa ou ao grupo social ao qual o ódio em questão se dirige, o banimento do racismo e da intolerância pode atender à mais exigente concepção de neutralidade. Mas este não parece ser um problema passível de ser resolvido unicamente no plano da abstração. Devemos olhar para os efeitos que a expressão de ódio racial causa nas minorias alvejadas por ela de forma um pouco mais atenta às circunstâncias concretas em que a vitimização se dá.

No caso específico da queima de cruzes não há espaço para dúvidas. Como já dissemos, não se trata apenas da expressão corriqueira de uma crença ou opinião qualquer: no contexto político e histórico dos Estados Unidos, uma cruz ardente é uma ameaça séria capaz de aterrorizar aqueles a quem se dirige. Por essa razão, Sunstein argumenta que uma preocupação mais forte com a equidade dos cidadãos dificilmente pode ser considerada uma violação da equidade: "Não há nada de partisan ou ilegítimo no reconhecimento de que um tipo especial de dano é causado por esse gênero de palavras de luta" [referindo-se à ação levada a cabo em R.A.V.] (SUNSTEIN, 1995, p. 192). No sistema estadunidense, as bases legais para tanto existem. Afinal, o caso Beauharnais ainda não foi explicitamente revogado, e, ainda que de forma duvidosa e incerta, pode sustentar o impedimento de libel de certos grupos sociais (SUNSTEIN, 1995, p. 198). Aliás, a própria Constituição dos Estados Unidos - que a Suprema Corte tem como missão defender - não é neutra no sentido preconizado por esse tribunal em R.A.V. Há ali um conjunto de provisões que inscreveram a igualdade no frontispício constitucional, como as emendas pós-Guerra Civil que aboliram a escravidão, eliminaram a cidadania de segunda classe e garantiram aos ex-escravos os direitos políticos plenos (As Emendas n. XIII, XIV e XV, respectivamente). Sunstein afirma que, se R.A.V. está certa, então a festejada lei dos direitos civis é inconstitucional, já que proíbe a demissão de um empregado em razão de sua etnia (embora seja permitido demiti-lo por um sem-número de razões). De acordo a racionalidade estabelecida em R.A.V., esse tipo de proibição não poderia ser considerada neutra, já que é capaz de “penalizar” alguém por suas convicções políticas. Não é perfeitamente possível imaginar um empregador branco que, por convicções segregacionistas, demita seu empregado negro? Algumas ações desse tipo têm certamente alguma dimensão expressiva (SUNSTEIN, 1995, p. 197). Entretanto, a mesma racionalidade que proíbe de demissões discriminatórias de mulheres e de negros pode ser invocada para 
proteger esses grupos, bem como homossexuais, de insultos e de intimidações, e pode fazê-lo em bases aceitavelmente neutras, porque compatível com a pluralidade social e política. Talvez seja por essas razões que a Corte em Virgina v. Black, ${ }^{17}$ de 2003, indicou que uma lei criminalizando a queima de cruzes poderia ser apoiada, desde que feita com adequação e precisão em sua técnica legislativa, de modo a ficar claro que ela tinha como alvo a intimidação e a ameaça, preservando a mera expressão política (O’BRIEN, 2005, p. 484).

Uma expressão racista é capaz de provocar um intenso e doloroso sofrimento emocional nos grupos atingidos por ela. A lei de Saint Paul penalizava a expressão justamente com base nesse estado subjetivo, falando em "ressentimento" e em "raiva". Contudo, se aceitamos a proposição de que a expressão capaz de causar algum tipo de incômodo na audiência dá causa à proibição, teríamos que grande parte da dissensão política poderia ser censurada, o que faz dessa asserção, pelo menos nesse nível de generalidade, um critério inaceitável para a regulação da liberdade de expressão. Jeremy Waldron, um crítico da liberalidade com que o sistema constitucional estadunidense trata expressões de ódio, rejeita o caráter subjetivista e psicologizante associados à punição de expressões "ofensivas" 18 exatamente por essa razão. Aceitar uma rationale como essa é perigoso para a liberdade de expressão porque se sentir ofendido é um efeito frequente e previsível da expressão veemente de discordâncias que deve ter seu lugar no debate público de temas candentes. Inspirando-se em passagem de Sobre a liberdade, de Mill, e preocupado com a liberdade de discussão pública, Waldron alerta-nos que aquilo que pode parecer simples vituperação nem sempre o é. Pode tratar-se "não da opressão da individualidade de outrem, mas do exercício da nossa própria individualidade” (WALDRON, 2012, p. 225-6). E a objeção de Waldron não é importante apenas para proteger uma ampla liberdade de expressão, mas também uma ampla liberdade religiosa: dado que as diferentes crenças religiosas são mutuamente "blasfemas", "heréticas", "irreverentes" e "ofensivas" (WALDRON, 2012, p. 127), a liberdade religiosa "não significa nada se não há o direito de ofender: isso é claro” (WALDRON, 2012, p. 130).

Mas podemos requalificar a questão da ofensa do seguinte modo: a raiva e o ressentimento que expressões racistas causam não seria de um tipo muito especial, portanto, capazes de justificar a censura? Será que atos de expressão que causam ressentimento ou raiva em virtude de, digamos, raça, credo ou sexo não poderiam sujeitar-se a um controle mais forte do que o ressentimento provocado por outros tipos de divisão? Sunstein parece endossar essa tese, reivindicando a especificidade e a legitimidade da censura de expressões que ecoam exclusões com certo lastro histórico, quando afirma que "só a obtusidade permitiria a alguém afirmar que a palavra 'fascista' ou 'porco' ou mesmo 'branquelo' ['honky'] produz os mesmos sentimentos que a palavra 'nigger'” (SUNSTEIN, 1995, p. 186). A teoria constitucional estadunidense, tal como entendida hoje, não reconhece, contudo, nenhuma diferença qualitativa entre as expressões acima. 
Que base teórica podemos mobilizar para justificar essa diferença? Não poderia ser, a nosso ver, a de que essa forma de ressentimento é mais intensa do que outras formas de ressentimento, causados, por exemplo, por antagonismos esportivos, porque isso seria o mesmo que aprofundar o caráter psicologizante do argumento, o que constitui um de seus pontos débeis. Recorrendo à própria história da sociedade em que o problema ocorre, agressões verbais contra minorias étnicas e expressões racistas em geral podem ser entendidas como meros prelúdios de coisas mais graves, como violência física, por exemplo, ou "exclusão, ou subordinação que não podem ser plausivelmente reduzidos a uma simples ofensa” (SUNSTEIN, 1995, p. 186). O problema, então, não é o ressentimento ou a raiva que a expressão produz nos ouvintes, mas o fato de que para além do sofrimento emocional, o que está em jogo é toda uma rede de direitos e oportunidades dos membros de minorias com um histórico de exclusão, direitos esses que podem ser ameaçados se os membros da maioria perpetradora da exclusão encontram livre curso para expressar seu ódio. Neste caso, a sensação de raiva que a expressão cause nas vítimas do ódio não chega a ser irrelevante, mas não é central. Outra vez, a relevância penal da questão advém de seus efeitos sobre o conjunto de direitos e de oportunidades das vítimas, e não exclusivamente de um estado psicológico determinado. Insultos racistas proferidos em uma universidade, por exemplo, podem ter o objetivo e o efeito de intimidar membros de minoria e lograr de fato sua exclusão do ambiente universitário, o que constitui uma privação séria de oportunidades e de direitos. Isso não pode ser de modo algum comparado ao ressentimento sentido por um cidadão que é insultado por sua calvície, ou ao ressentimento que se sente durante acalorada discussão política. Uma vez mais recorrendo a Sunstein, a diferença é que minorias historicamente discriminadas podem sentir-se mais do que ofendidas diante de expressões desse tipo. "Pessoas confrontadas com expressões de ódio podem experimentar uma forma de 'silenciamento' no sentido de que se tornam relutantes em expressar-se e não são ouvidos quando o fazem” (SUNSTEIN, 1995, p. 186).

Uma contrarrazão forte a este argumento é que mesmo que nos limitemos a essa forma limitada e historicamente justificada, por assim dizer, de restrição a "ofensas", ainda assim esse critério poderia autorizar a censura de parte importante do debate público contemporâneo. A discussão sobre política externa, por exemplo, ou sobre aborto, serviço militar obrigatório, política criminal e previdenciária e muitos outros temas candentes pode facilmente tocar em questões raciais e "provocar raiva ou ressentimento com base na raça”, para usar a expressão da lei antidiscriminatória da cidade de Sant Paul (SUNSTEIN, 1995, p. 186).

Thomas Streeter (1995, p. 32-33) propõe uma questão - cuja formulação ele credita ao crítico literário afro-estadunidense Henry Louis Gates - capaz de nos ajudar neste ponto fornecendo-nos uma razão adicional pela qual a pura e simples ofensividade não pode dar causa a censura. Imaginemos que as expressões de ódio a seguir 
sejam dirigidas a membros de minorias étnicas beneficiários de uma política de cotas para a entrada em universidades públicas em um país ou região com um forte histórico de exclusão e de racismo:

\section{Expressão $A$ :}

"Sai da minha frente, animal selvagem!"

\section{Expressão $B$ :}

"Fulano: se você tem dificuldade para acompanhar as aulas aqui, deveria perceber que a culpa não é sua. Isso corre simplesmente pelo fato de você ser beneficiário de uma política equivocada e prejudicial de ação afirmativa que coloca estudantes negros pouco qualificados, pouco preparados e frequentemente pouco talentosos em ambientes educacionais exigentes como este. Os objetivos da política igualitária podem ser bem-intencionados, mas dado que testes de aptidão revelam que afro-americanos estão quase um degrau inteiro abaixo da média, mesmo descontadas as disparidades socioeconômicas, os objetivos estão profundamente mal conduzidos. A verdade é que provavelmente você não pertence a este lugar, e tua experiência na faculdade será uma longa descida ladeira abaixo”.

Diante de ambas as expressões, e reconhecendo de antemão que as duas são extremamente racistas, pergunta-se: qual delas é mais ofensiva e mais dolorosa para a vítima? Acreditamos que não haveria muita controvérsia quanto ao reconhecimento de que o segundo discurso agride mais, fere mais, é capaz de causar mais dano psicológico a um aluno membro de uma minoria que entrou na universidade pelas portas de um sistema de ação afirmativa. Esse gênero de expressão é mais ofensivo e causa mais dano porque, enquanto no exemplo em que o insulto é mais direto, o que se revela é um indivíduo doentiamente racista, no exemplo B é "a instituição universitária que parece olhar o aluno de cima, dizendo-lhe que ele não se encaixa ali” (STREETER, 1995, p. 34). Entretanto, a despeito dessa diferença entre as expressões, diferença essa que favorece o insulto direto em relação à segunda fala, se o critério é a ofensividade da expressão, os códigos de expressão das universidades estadunidenses alcançariam apenas a primeira fala. Isso porque o que os separa não é o conteúdo, que em ambos é racista ao extremo, mas o estilo. O segundo tipo de expressão apela a razões e a argumentos que, por mais que os consideremos falsos, inválidos e equivocados, ainda são argumentos, ao fim e ao cabo. E aqui não estamos a falar apenas das universidades, mas de regras de validade mais geral.

Acreditamos que chegamos, portanto, a dois critérios gerais para regulação de expressões de ódio. O primeiro é que a "raiva” ou a "mágoa” que uma expressão cause não pode fornecer, sozinha, base alguma para a regulação. Isso não significa, contudo, que não se possa regular expressões de ódio. Significa apenas que eles não podem 
ser regulados por essa razão. A segunda é que expressões que apelem a algum tipo de habilidade deliberativa podem gozar ao menos de certa presunção de boa-fé, por assim dizer, capaz de fazê-la passar pelos filtros que estamos discutindo. Isso porque nosso objetivo, mais do que reprimir as convicções racistas per se, é preservar os direitos constitucionais e as oportunidades das minorias visadas pelos racistas. Considerando a importância que o debate político tem e deve ter em um regime democrático e pluralista, é razoável afirmar que expressões racistas que se resumem a gritos e a insultos têm menos valor do que expressões racistas que apelam a argumentos, o que justifica um tratamento diferente. Isso a despeito do desprazer que eventualmente possamos ter ao escutar argumentos racistas, misóginos ou homofóbicos. O debate - que ganhou força no Brasil nos últimos anos - sobre a conveniência ou não de adotarmos ações afirmativas no acesso à universidade pública ilustra muito bem este ponto. Nesse debate, defensores e detratores de cotas raciais acusam-se mutuamente de racismo, e, se alguma dessas acusações for aceita como razão suficiente para calar o interlocutor, o prejuízo será do próprio debate sobre a questão racial no Brasil, que, por conta dessa mesma polêmica, tem ganhado em franqueza e avançado de forma inédita. As expressões que, de alguma forma, apelam à razão deliberativa podem ser respondidas com base em argumentos, enquanto o insulto e os epítetos lançados aos gritos só podem ser o prelúdio de retirada humilde e calada, da fuga ou da violência física. Ao menos parcela dos críticos da excessiva liberalidade com que expressões desse tipo são tratadas nos Estados Unidos parece concordar com este critério. Falando de um incidente racial ocorrido em Stanford há alguns anos, ${ }^{19}$ um grupo de acadêmicos críticos da forma excessivamente liberal com que expressões raciais são tratadas pelo direito constitucional contemporâneo deu a entender que os racistas deveriam ser punidos pelo fato de que sua manifestação não tinha características deliberativas. Seu único objetivo era "acabar com a discussão, em vez de dar-lhe continuidade. Não se tratava de uma refutação do argumento dos estudantes negros, mas um ataque à postura dos negros de dedicar-se a um diálogo intelectual” (MATSUDA et al., 1993, p. 7-8).

Com a ajuda de Jeremy Waldron, que fez uma escolha clara pelo individualismo ético (WALDRON, 2012, p. 56), podemos acrescentar um terceiro parâmetro: a rationale da punibilidade precisa incorporar uma distinção cuidadosa entre a difamação de membros individuais de uma religião via características do grupo - que deve ser punível - e a difamação da própria religião, que deve ter livre curso em uma sociedade que preze as liberdades públicas. Não é um grupo enquanto tal (comunidade, religião, nação, cultura etc.) que se deseja proteger, mas sim a liberdade dos indivíduos que o integram. Indivíduos não são protegidos por leis que, digamos, criminalizam o ataque a uma doutrina religiosa enquanto tal, como as leis contra a blasfêmia (WALDRON, 2012, p. 122-125). ${ }^{20}$ A punibilidade de expressões de ódio deve guiar-se pelo intento de proteger o que chama de "dignidade" individual e "uma espécie 
preciosa de bem público: uma atmosfera aberta e convidativa na qual todos tenham a oportunidade de viver suas vidas, criar suas famílias e levar a cabo seus negócios e vocações” (WALDRON, 2012, p. 16). E “a dignidade de uma pessoa”, diz ele, "não é apenas uma espécie de aura kantiana" (WALDRON, 2012, p. 5), mas a capacidade de membros de minorias vulneráveis "que até o passado recente foram odiadas ou desprezadas no interior da sociedade" de "interagir em pé de igualdade com os outros[...] em público, nas ruas, nas lojas, nos negócios, e a ser tratados - assim como todos os demais - como objeto da preocupação e proteção social” (WALDRON, 2012, p. 5).

Ficariam de fora da proteção constitucional à liberdade de expressão, desta forma, apenas certas categorias de expressões de ódio. Evidentemente, haveria casos pouco claros, situações-limite de difícil classificação. Mas isso parece inevitável; mesmo a mais clara definição da liberdade de expressão tem de confrontar-se com problemas difíceis que parecem escapar a toda tentativa de estabelecer um critério.

Nossa ênfase nas consequências que a expressão tem no mundo real (SUNSTEIN, 1995, p. 192), mais do que no conteúdo ideológico da mensagem, não satisfaz um opositor de controles sobre expressões de ódio, como Ronald Dworkin, quem apela a argumento que, em última instância é uma defesa da autonomia individual, no sentido de que qualquer controle sobre a expressão de ódio seria paternalista. Segundo ele, a liberdade de expressão possui um "valor intrínseco" que está acima de seu eventual "valor instrumental": essa liberdade não deve ser protegida apenas porque nos proporciona algo que consideramos valioso (por que sem ela o autogoverno coletivo é impossível, porque com ela poderemos conhecer mais e melhor o mundo etc.). A liberdade de expressão adequadamente compreendida, para ele, tem seu valor se estendidas a todos, sem distinção, inclusive àqueles que queimam cruzes e que ameaçam seus concidadãos, pois é assim que "o governo trata todos os seus membros adultos, exceto aqueles que são incapazes, com agentes morais responsáveis”. Pessoas nessa condição caracterizam-se por

formar suas próprias opiniões sobre o que é bom ou ruim em política, ou o que é verdadeiro ou falso em matéria de justiça ou fé. O governo insulta seus cidadãos, e nega-lhes sua responsabilidade moral, quando determina que não é confiável que eles ouçam opiniões que os possam persuadir a converter-se a convicções perigosas ou ofensivas. Mantemos nossa dignidade como indivíduos apenas se insistirmos que ninguém nenhum agente público ou maioria - tem o direito de privar-nos de uma opinião com base em que não temos as condições de ouvi-la e considerá-la. (DWORKIN, 1996, p. 200)

Qualquer que seja o dano causado por um discurso ou a quantidade de indivíduos atingidos por ele, sua supressão representaria uma forma de paternalismo incompatível 
com a ideia de que somos sujeitos morais plenos. Em suma, a questão é que as pessoas devem poder falar livremente porque têm um direito moral a fazê-lo, independentemente do conteúdo de sua mensagem. Não que a justificativa moral torne a liberdade de expressão absoluta, mas torna-a mais robusta do que a justificativa meramente instrumental: se a liberdade de expressão só tem valor na medida em que promove outro bem, podemos deparar-nos com situações em que esse bem estaria mais bem protegido na medida em que o discurso fosse suprimido. O problema desse argumento de Dworkin é que ele ignora a possibilidade de que algumas expressões de ódio podem causar danos às suas vítimas. No caso dessas expressões que causem dano a minorias, tratar os responsáveis pela expressão como sujeitos morais responsáveis pode significar fazê-los responder pelo dano que causem. Se isso pode representar a exclusão de certos discursos da esfera deliberativa e, nesse sentido, impor-lhes uma desigualdade política, também representa um impedimento a que esses mesmos racistas imponham uma exclusão forçada aos grupos discriminados. Diante da objeção frequente na discussão estadunidense de que uma restrição a expressões de ódio mutila a discussão pública, Jeremy Waldron vale-se de Geoffrey Stone para responder que o objetivo é exatamente esse: "Sem elas [as restrições], o debate público seria mais áspero, intimidante e desmoralizador para aqueles que integram grupos vulneráveis” (STONE apud WALDRON, 2012, p. 154).

A conexão entre determinadas formas de expressão de ódio e a violência física efetiva é mais que uma hipótese remota. No último genocídio do século XX, ocorrido em Ruanda em 1994, um número estimado entre 500 mil e um milhão de pessoas, em sua imensa maioria tutsis e hutus moderados, foram assassinadas por extremistas hutus ao longo de apenas cem dias. Parte dessas mortes é creditada ao ódio propagado e inflamado pelas ondas do rádio (GOUREVITCH, 2006), principalmente por meio da Radio Télévision Libre des Mille Collines (RTLM). Alguns anos mais tarde, um governo liderado pelos tutsis proibiu partidos políticos de apelar à identidade racial (LEWIS, 2007, p. 166), uma restrição à expressão que, se não é considerado legítima nas condições estadunidenses, é perfeitamente compreensível nas circunstâncias trágicas desse pequeno país africano. ${ }^{21}$

Ruanda não é o único caso de restrição a expressões de ódio racial, e um pouquinho de direito comparado neste ponto não nos faria mal. A difamação em bases étnicas e raciais é proibida em muitas democracias exuberantes, aparentemente com poucos danos ao sistema de expressão livre (SUNSTEIN, 1995, p. 15). A Alemanha criminaliza seriamente a exibição da suástica ou qualquer outro símbolo nazista. Em outros 11 países europeus, é crime negar o Holocausto. O Race Relations Act ${ }^{22}$ do Reino Unido proíbe expressões de ódio racial, não apenas quando se trate de expressão que conduza à violência, mas de qualquer tipo, com o argumento de que minorias devem ser protegidas de insultos raciais. A Austrália pune "ações que insultam, humilham ou intimidam um grupo de pessoas devido a sua raça, cor, origem étnica 
ou nacional”, excluindo da punição expressões com "propósito acadêmico, artístico, científico" ou com qualquer outro propósito de interesse público (WALDRON, 2012, p. 190-191). No Brasil, a Constituição de 1988 criminaliza seriamente o racismo (artigo $5^{\circ}$, XLII), declarando-o crime inafiançável e imprescritível, no que foi seguida pela Lei n. 7.716/89 (a Lei Afonso Arinos, de 1951, considerava o racismo uma contravenção penal). Dificilmente alguém poderia afirmar que nesses países o sistema democrático está desabando por conta de criminalização de expressões de ódio. Uma das funções da razão pública é justamente expressar um dever de civilidade democrática de tolerância. ${ }^{23}$ Waldron também ressalta a interdependência entre democracia e respeito mútuo (WALDRON, 2012, p. 157).

Ainda no Brasil, uma controvérsia que coloca a liberdade de expressão e a restrição ao preconceito em campos antitéticos está em andamento, com respeito aos Projetos de Lei da Câmara (PLC) n. 122/2006 (no Senado) e Projeto de Lei n. 5.003/200124 (na Câmara dos Deputados), que propõem uma alteração na Lei n. 7.716/89, ${ }^{25}$ aumentando-lhe o escopo e criminalizando a discriminação ou o preconceito de gênero, sexo, orientação sexual e identidade de gênero, permitindo que a motivação homofóbica nos crimes discriminatórios passe a ser considerada no processo penal e impedindo que estabelecimentos e empresas que adotem posturas discriminatórias possam receber incentivos fiscais, créditos públicos e participar em licitações. Grupos religiosos acusam o projeto de lei de autoritário, no sentido de que poderá comprometer-lhes a liberdade de predicar contra a homossexualidade. As implicações do projeto para a liberdade de expressão, contudo, são mínimas, se interpretamos a lei sob a ótica dos argumentos que vimos desenvolvendo. ${ }^{26}$ Os tipos penais criados pela Lei n. 7.716/89 são ostensivamente focados em ações de privação ou tentativa de privação de direitos e liberdades das categorias protegidas. Verbos como "impedir" e "obstar" repetem-se uma e outra vez no texto da lei: "Impedir ou obstar o acesso de alguém [...] a qualquer cargo da Administração", "Negar ou obstar emprego em empresa privada”, "Recusar ou impedir acesso a estabelecimento comercial, negando-se a servir, atender ou receber cliente ou comprador", "recusar, negar ou impedir a inscrição ou ingresso de aluno em estabelecimento de ensino público ou privado de qualquer grau", "Impedir o acesso ou recusar atendimento em estabelecimentos "comerciais", "de ensino", a "entradas sociais em edifícios públicos ou residenciais e elevadores", ou ainda a "transportes públicos", e, finalmente, "Impedir ou obstar, por qualquer meio ou forma, o casamento ou convivência familiar e social”. O escopo da lei e do projeto que propõe a criminalização de condutas discriminatórias de fundo homofóbico é claramente o de fazer com que homossexuais não precisem mais, por exemplo, temer a demissão sumária no caso de sua inclinação sexual se tornar pública.

As implicações diretamente vinculadas à liberdade de expressão estão no final do documento. Se bem o artigo 20 tenha uma redação mais aberta e ampla, penalizando a conduta de "induzir ou incitar a discriminação ou preconceito de raça, cor, etnia, 
religião ou procedência nacional”, acreditamos, de acordo com a argumentação que vimos desenvolvendo, que o tipo deve ser interpretado em consonância com o restante do documento legal. A expressão deve ser suprimida caso se resuma a insultos dirigidos contra grupos historicamente privados de direitos. No caso de a expressão apelar para habilidades deliberativas, a punição deve executar-se apenas na medida em que a expressão esteja relacionada de forma mais ou menos direta com a privação concreta de direitos. É uma distinção desse tipo que nos permitiria punir a incitação à demissão de um homossexual, por exemplo, preservando o direito de crença religiosa em que a homossexualidade é "pecado", desde que essa crença sirva apenas como guia de conduta dos indivíduos que a abraçam voluntariamente. Isso se torna mais evidente diante do fato de que a lei autoriza o juiz a tomar medidas duras, no caso de a incitação ao racismo ser feita "por intermédio dos meios de comunicação social ou publicação de qualquer natureza". Nesse caso, o juiz poderá determinar "o recolhimento imediato ou a busca e apreensão dos exemplares do material respectivo" e/ ou "a cessação das respectivas transmissões radiofônicas ou televisivas”. No nosso entender, a única forma de expressão punível per se no documento é a da fabricação, comercialização, distribuição e veiculação da suástica "para fins de divulgação do nazismo". Mas a suástica, convenhamos, não faz falta à nossa deliberação pública.

\section{CONCLUSÕES}

Como vimos ao longo das páginas anteriores, uma característica importante do sistema de proteção à liberdade de expressão nos Estados Unidos é a centralidade atribuída ao discurso político, categoria na qual expressões de ódio e de preconceito costumam encaixar-se. Uma justificativa para esse "libertarianismo civil" (a expressão é de Mark Graber) aplicado à liberdade de expressão é a de que ele mantém a esfera pública aberta. Tal ideal de regulação, contudo, parece-nos inadequado se levamos em conta que ao menos certos tipos de expressão de ódio têm justamente o efeito de bloquear o acesso de suas vítimas à esfera pública.

Por outro lado, sustentamos que a criminalização tout court de toda a qualquer forma de preconceito não é desejável do ponto de vista normativo. Em primeiro lugar, porque isso abre a possibilidade de censura de obras de valor científico, histórico, literário e artístico. Em segundo lugar, porque a definição de preconceito é parte constitutiva de certas controvérsias públicas. Pense-se por exemplo na discussão sobre ações afirmativas, em que acusações cruzadas de racismo entre defensores e opositores dessa política pública são frequentes. Além do mais, e se o que vimos defendendo ao longo destas páginas faz sentido, não é punir o preconceito enquanto tal o objetivo primordial de um sistema bem desenhado de regulação de expressões de ódio, e sim o de oferecer proteção aos direitos constitucionais dos indivíduos e o de manter o espaço público aberto e receptivo. A questão, assim, reside no desenvolvimento dos critérios 
para o uso da coerção coletiva. Foi o que tentamos fazer neste artigo: oferecer um conjunto de parâmetros para se pensar a regulação das chamadas expressões de ódio numa democracia. Neste exercício, autores como Cass Sunstein e Jeremy Waldron, entre outros, foram de importância vital.

E um critério importante é o de que o fato de um discurso ou expressão inspirar raiva ou mágoa não deve constituir razão suficiente para a censura de uma expressão. Isto pela razão de que é da natureza da discussão pública a possibilidade de que aqueles que dela tomamos parte nos sintamos ofendidos, o que não é incomum de ocorrer quando nossa visão de mundo é atacada ou ridicularizada. A criminalização da blasfêmia, por exemplo, um ataque frontal à liberdade de expressão, muitas vezes é defendida ou justificada apelando-se à rationale de que a blasfêmia "ofende" os fiéis da fé atingida. De acordo com a perspectiva que vimos tentando defender aqui, no entanto, não é aceitável o uso dos instrumentos da coerção coletiva para sustentar a integridade de doutrinas religiosas, muito menos ao custo da liberdade de expressão.

Outro critério importante propõe tratamento diferenciado entre, de um lado, expressões que, embora carregadas de preconceito, apelem a habilidades deliberativas do interlocutor, e, de outro lado, expressões que sejam puro epíteto. O primeiro tipo de expressão pode ser entendido como um convite à discussão, sendo, portanto, tolerável, a menos que tenha relação causal identificável com a violência e a privação de direitos. O segundo tipo, especialmente se dirigido a minorias historicamente oprimidas em determinado contexto, manifesta a intenção de, por meio da intimidação, bloquear a esfera pública aos grupos visados, o que constitui razão mais do que suficiente para a intervenção estatal.

NOTAS

* Este artigo é parte modificada de tese de doutorado que, sob a perspectiva da teoria política normativa, procurou refletir sobre a importância da liberdade de expressão para a vida democrática (ver BARROSO, 2009). Uma versão anterior deste texto foi apresentada no $7^{\circ}$ Encontro da Associação Brasileira de Ciência Política, quando recebeu valiosas críticas e sugestões do público presente e principalmente do debatedor, Ricardo Silva. Agradeço ainda a Lucas Petroni, Marcos Paulo Lucca-Silveira, Renato Franceschini, San Romanelli Assumpção, Raphael Neves, Ingrid Cyfer e Felipe Silva pela leitura atenta e pelos comentários que muito contribuíram para o aperfeiçoamento do texto. Evidentemente, as falhas que o trabalho possa ter são de minha inteira e exclusiva responsabilidade. 
1 Essa regra foi formulada por Louis Brandeis em Whitney v. California, 274 U. S. 357 (1927). Disponível em: <http://www.law.cornell.edu/supct/html/historics/USSC_CR_0274_0357_ZS.html> Acesso em: 29 jul. 2013.

2 New York Times Co. v. Sullivan, 376 U.S. 254 (1964). Disponível em: <http://www.law.cornell.edu/ supct/html/historics/USSC_CR_0376_0254_ZS.html>. E Brandenburg v. Ohio, 395 U. S 444 (1969). Disponível em: <http://www.law.cornell.edu/supct/html/historics/USSC_CR_0395_0444_ZS.html> Acesso em: 29 jul. 2013.

3 Ameaças, tentativas de suborno, perjúrio, conspiração criminosa, exercício ilegal da medicina ou da advocacia, formação de cartel, contratação de serviços criminosos, além de assédio sexual e racial também pertencem à categoria de expressão de pequeno valor.

4 Miller v. California, 413 U.S. 15 (1973). Disponível em: <http://www.law.cornell.edu/supct/html/historics/ USSC_CR_0413_0015_ZS.html> Acesso em: 29 jul. 2013.

5 Ver Matsuda; Lawrence III; Delgado; Crenshaw (1993, p. 141).

6 Beauharnais v. Illinois, 343 U. S. 250 (1952). Disponível em: <http://www.bc.edu/bc_org/avp/cas/ comm/free_speech/beauharnais.html> Acesso em: 29 jul. 2013.

7 A decisão foi anterior à histórica sentença do caso Brown v. Board of Education, de 1954, que pôs fim à segregação racial nas escolas públicas.

8 Encontrar uma expressão em português com a mesma carga semântica dessa locução não é tarefa das mais fáceis. Embora a expressão "palavras de luta" não transmita com exatidão a ideia de fighting words, não encontramos alternativa melhor, e é assim que doravante traduziremos a expressão neste trabalho.

9 Chaplinsky v. State of New Hampshire, 315 U. S. 568 (1942). Disponível em: <http://www.law.cornell.edu/ supct/html/historics/USSC_CR_0315_0568_ZS.html> Acesso em: 29 jul. 2013.

10 Collin v. Smith, 578 F.2d 1197 (1978). Disponível em: <http://www.law.umkc.edu/faculty/projects/ ftrials/conlaw/colinvsmith.html> Acesso em: 29 jul. 2013.

11 R.A.V.v. City of Saint Paul, Minnesota, 505 U.S. 377 (1992). Disponível em: <http://www.law.cornell.edu/ supct/html/90-7675.ZS.html> Acesso em: 29 jul. 2013.

12 Os exemplos foram retirados de Cohen (1993, p. 207).

13 Doe v. Michigan 721 F. Supp. 852 (E.D. Mich 1989). Disponível em: <http://www.bc.edu/bc_org/ avp/cas/comm/free_speech/doe.html> Acesso em: 29 jul. 2013.

14 Texas v. Johnson 491 U. S. 397 (1989). Disponível em: <http://www.law.cornell.edu/supct/html/historics/ USSC_CR_0491_0397_ZS.html>Acesso em: 29 jul. 2013.

15 O caso Sullivan, de 1964 - já mencionado acima - é determinante da forma como se compreende a liberdade de expressão nos Estados Unidos: nele, contrapunham-se o jornal The New York Times (que publicara anúncio pago por grupo que apoiava Martin Luther King) e um oficial de polícia do Alabama que se considerou difamado pelo anúncio. O tribunal constitucional reconheceu ali a absoluta centralidade de liberdade de expressão para a vida democrática e estendeu a proteção à expressão que de alguma forma se entenda como "política". A partir desse axioma, a Corte inverteu o ônus da prova em casos de difamação de figuras públicas (incluindo aí qualquer pessoa que ocupe um cargo público, eleita ou não). Para beneficiar-se de uma ação de libel, autoridades públicas passaram a ter de provar a falsidade da afirmação de seus críticos, mas também de demonstrar que eles a fizeram sabendo tratar-se de uma falsidade, ou que pelo menos tivessem agido com imprudente desprezo (reckless disregard) pela veracidade ou falsidade da afirmação. Uma boa narrativa do caso Sullivan encontra-se em Lewis (1992).

16 Entretanto, se a lei de propriedade é usada para invocar o fechamento de uma arena pública importante, a legitimidade desaparece. É o que ocorre, a título de exemplo, se manifestantes ou partidários de determinado candidato são impedidos de distribuir panfletos no interior de um centro de compras com a justificativa de que se 
trata de um espaço privado (SUNSTEIN, 1995, p. 183). Apesar de privado, não é uma residência, mas um espaço de circulação pública mais geral, e não pode ser tratado como se fosse a sala de estar do proprietário do local.

17 Virginia v. Black, 538 U. S. 343 (2003). Disponível em: <http://www.law.cornell.edu/supct/html/011107.ZS.html> Acesso em: 29 jul. 2013.

18 Waldron propõe ainda a substituição da locução de "expressão de ódio" por "difamação de grupo" (group libel) em razão do caráter psicologizante da primeira (WALDRON, 2012, p. 33).

19 Alunos negros da universidade disseram que Beethoven tinha ancestrais africanos. Em resposta, alguns alunos brancos fizeram uma caricatura de Beethoven na qual este era representado com a pele escura, os lábios grossos e o cabelo crespo. Sob o desenho, podia-se ler: "Isto é o que vocês são. Vocês e todos os seus irmãos e irmãs afro-americanos. É uma piada pensar que vocês poderiam algum dia ser um Beethoven. Vocês só podem ser uma caricatura do verdadeiro gênio".

20 Os casos de Salman Rushdie e o das charges de Maomé publicadas na Dinamarca são exemplos eloquentes da importância dessa observação de Waldron.

21 Analogamente, perguntamo-nos se não é possível supor alguma relação causal entre a pregação de ódio contra os direitos humanos facilmente escutáveis em estações de rádio no Brasil e as amplas e costumeiras violações de direitos humanos cometidas pelas forças policiais brasileiras.

22 Disponível em: <http://www.statutelaw.gov.uk/content.aspx?ActiveTextDocld=2059995> Acesso em: 29 jul. 2013

23 Devo esta observação a San Romanelli Assumpção.

24 Disponível em: <http://www2.camara.gov.br/internet/proposicoes/chamadaExterna.html?link=http://www. camara.gov.br/internet/sileg/Prop_Detalhe.asp?id=31842> Acesso em: 29 jul. 2013.

25 Disponível em: <http://www.planalto.gov.br/CCIVIL/Leis/L7716.htm> Acesso em: 29 jul. 2013.

26 Com o propósito de dissipar semelhante temor, a Senadora Marta Suplicy apresentou substitutivo no qual se incluiu artigo com o seguinte teor: "O disposto nesta Lei não se aplica à manifestação pacífica de pensamento decorrente da fé e da moral fundada na liberdade de consciência, de crença e de religião de que trata o inciso VI do art. $5^{\circ}$ da Constituição Federal" (o texto da relatoria com o substitutivo foi consultado em: <http://legis.senado.leg.br/ mateweb/arquivos/mate-pdf/100548.pdf>, e acessado em 29 jul. 2013).

\section{REFERÊNCIAS BIBLIOGRÁFICAS}

BARROSO, Júlio. Democracia e liberdade de expressão: contribuições para uma interpretação política da liberdade de palavra. 2009. Tese (Doutorado em Ciência Política) - Programa de Pós-Graduação em Ciência Política, Faculdade de Filosofia, Letras e Ciências Humanas da USP, São Paulo.

COHEN, Joshua. Freedom of expression. Philosophy and Public Affairs, v. 22, n. 3, p. 207-263, verão de 1993. DWORKIN, Ronald. Why must speech be free? Freedom's law: the moral reading of the american constitution. Harvard University Press, 1996.

FISK, Robert. Offended by Shakespeare? Let's ban him. The Independent, 8 de março de 2008. Disponível em: <http://www.independent.co.uk/opinion/commentators/fisk/robert-fisk-offended-byshakespeare-lets-banhim-793167.html>. Acesso em: 29 jul. 2013.

GOUREVITCH, Philip. Gostaríamos de informá-1o de que amanhã seremos mortos com nossas famílias - Histórias de Ruanda. São Paulo: Companhia das Letras, 2006.

GRABER, Mark. Transformimg Free Speech - The Ambiguos Legacy of Civil Libertarianism. Berkeley/Los Angeles: 
University of California Press, 1991.

LEWIS, Anthony. Make no law: the Sullivan case and the first amendment. Vintage, 1992.

Basic Books, 2007. Freedom for the thought that we hate: a biography of the first amendment. Nova Iorque:

MADISON, James. Writings. Nova Iorque: Penguin, 1999.

MATSUDA, Mari. J.; LAWRENCE III, C. R. L.; DELGADO, Richard; CRENSHAW, Kimberlè. W. Words that wound: critical race theory, assaultive speech, and the first amendment. Westview Press, 1993.

MILL, John Stuart. Sobre a liberdade. Petrópolis: Vozes, 1991.

NASCIMENTO, Sebastião. Seja qual for a língua, a liberdade não admite discriminação. Mimeo, 2007.

O’BRIEN, D. M. Constitutional law and politics. 6. ed. Nova Iorque: W. W. Norton, 2005, v. 2.

POST, Robert C. Meiklejohn's mistake: individual autonomy and the reform of public discourse. Constitutional domains - democracy, community, management. Londres: Harvard University Press, 1995a.

. The constitutional concept of public discourse: outrageous opinion, democratic

deliberation and Hustler Magazine v. Falwell. Constitutional domains - democracy, community, management. Londres: Harvard University Press, 1995b.

RABBAN, David M. Free speech in its forgotten years, 1870-1920. Cambridge: Cambridge University Press, 1997.

RAWLS, John. O liberalismo político. São Paulo: Ática, 2000.

Justiça como equidade - uma reformulação. São Paulo: Martins Fontes, 2003.

REICH, Howard. "Rewakening the ghosts". Chicago Tribune, 16 de janeiro de 2013. Disponível em: <http://articles.chicagotribune.com/2013-01-16/opinion/chi-perspec-reawakening-the-ghosts-of-skokie20130115_1_illinois-holocaust-museum-survivors-skokie>. Acesso em: 29 jul. 2013.

SCANLON, T. M. A theory of freedom of expression. The difficulty of tolerance: essays in political philosophy. Cambridge: Cambridge University Press, 2003a.

. Freedom of expression and categories of expression. The difficulty of tolerance: essays in political philosophy. Cambridge: Cambridge University Press, 2003b.

STEVENS, John Paul. Sould hate speech be outlawed?. New York Review of Books, 7 de junho de 2012., Disponível em: <http://www.nybooks.com/articles/archives/2012/jun/07/should-hate-speech-beoutlawed/> . Acesso em: 29 jul. 2013.

STRAUSS, David. A., "Freedom of Speech and the Common-Law Constitution", in: BOLLINGER, L. C.; STONE, G. R. Eternally Vigilant: Free Speech in the Modern Era. University of Chicago Press, 2003.

STREETER, Thomas. Free speech, language and the rule of law. In: ALLEN, David. Freeing the first amendment: critical perspectives on freedom of expression. Nova Iorque: NYU Press, 1995.

SUNSTEIN, Cass R. Democracy and the problem of free speech. Free Press, 1995.

WALDRON, Jeremy. The harm in hate speech. Cambridge: Harvard University Press, 2012.

\section{LEGISLAC̣̃̃ES CITADAS OU CONSULTADAS}

BRASIL

Constituição (1988). 42. ed. São Paulo: Saraiva, 2009;

Lei n. 7.716, de 5 de janeiro de 1989 ;

Projeto de Lei da Câmara n. 122/2006.

\section{ESTADOS UNIDOS}

The Constitution of the United States of America DECISÕES DA SUPREMA CORTE

Whitney v. California, 274 U. S. 357 (1927);

Chaplinsky v. State of New Hampshire, 315 U. S. 568 (1942);

Beauharnais v. Illinois, 343 U. S. 250 (1952);

New York Times Co. v. Sullivan, 376 U.S. 254 (1964);

Brandenburg v. Ohio, 395 U. S 444 (1969);

Miller v. California, 413 U.S. 15 (1973);

Hustler Magazine, Inc. v. Falwell, 485 U.S. 46 (1988);

Texas v. Johnson, 491 U.S. 397 (1989);

R. A.V. v. City of Saint Paul, Minnesota, 505 U.S. 377 (1992);

Virginia v. Black, 538 U. S. 343 (2003). 


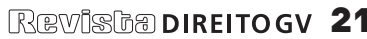

DECISÕES JUDICIAIS DE INSTÂNCIAS INFERIORES

Collin v. Smith, 578 F.2d 1197 (1978);

Doe v. Michigan 721 F. Supp. 852 (E.D. Mich 1989).

GRÃ-BRETANHA

Lei britânica sobre as relações raciais (Race relations Act)
JÚLIO CÉSAR CASARIN BARROSO SILVA: $06 \mathbf{3}$

Júlio César Casarin Barroso Silva

Guarulhos - SP - Brasil juliocesarcbslahotmail.com
Professor Adjunto de Teoria Política Junto à Escola de Filosofia, Letras e Ciências Humanas (EFLCH) da Universidade Federal de São Paulo (Unifesp) 
